DOI: https://doi.org/10.32839/2304-5809/2019-6-70-72

UDC 811.111'36

Shevchenko Maryna, Bikesina Anastasia

Donbas State Pedagogical University

\title{
STYLISTIC AND PHILOSOPHICAL MAINTENANCE OF EPISTLES OF A. VON DROSTE-HULSHOFF
}

Summary. The article observes stylistic and philosophical maintenance of Anette von Droste-Hulshoff epistles, whose poetry is unjustly little-known not only to a wide range of readers, but even to philologists. Annete's poetry is marked by acute problematic of it's time, which does not loose its topicality novadays. A number of verses from a cycle written by A. von Droste-Hulshoff has been chosen for analysis and the problematic of each is to be defined. The main topic of each chosen verse is love feelings. Although A. von Froste-Hulshoff is not well-known author her works are worth reading. In her works she doesn't just show love feelings - she shows a range of emotions and different kinds of love. But what is important, that in the centre of any plot is the woman, whose life is not easy and who has to make a difficult decision. Since a large number of works are poems-appeals, they have a significant number of rhetorical questions ("Wie sollte mir das Herz nicht pochen?", "Ist nicht mein Zürnen selber deinem gleich?", "Du zweifelst an der Sympathie / Zu einem Wesen dir zu eigen?" Keywords: poetry, cycle, stylistic, author, problematic, feelings.

Шевченко М.Ю., Бікезіна А.Д. Донбаський державний педагогічний університет

\section{СТИЛІСТИЧНО-ФІЛОСОФСЬКИЙ ЗМІСТ ЕПІСТОЛ А. VON DROSTE-HULSHOFF}

Анотація. У статті розглядаються стилістичній та філософрській зміст епістол Anette von DrosteHulshoff, чия поезія мало відома не лише широкому колу читачів, але й фрілологам. Поезія Annete характеризується гострою проблематикою свого часу, яка і досі не втрачає своєї актуальності. Ряд віршів циклу, написаного A. von Droste-Hulshoff, був обраний для аналізу і визначення проблематики кожного з них. Основною темою кожного обраного вірша е любовні почуття. Усі представлені поезії поєднані тужливим усвідомленням авторкою нестримною різниці у віці з коханим, розумінням усіх перешкод і бід, що приносить закоханість немолодої жінки у юнака. Так, три епістоли, присвячені Л. Шюкінгу, пронихливо змальовують непрості стосунки ліричної героїні з коханим: різниця у віці призводить не лише до психологічних конфліктів, а й до відвертого непорозуміння закоханих, адже старша жінка має більший життевий досвід, вона позбавлена егоїзму та самозамилування юності, вона може дозволити собі чесність у словах і у діях усепереч суспільним нормам. "Abschied von der Jugend» - лірико-фрілософська поезія про прощання з молодістю, у якій з великою виразністю лірична героїня висловлює свої роздуми про людський вік і його неминуче вгасання. Людина, старість якої невмолимо наближається, порівнюеться з вигнанцем, що стоїть на кордоні рідної землі; з могильщиком, що тужить за померлими подібно ліричної героїні з їі тугою за втраченими можливостями. Образ понурого мандрівника, в серщі якого зосереджені усі сподівання і водночас уся журба («So an seiner Jugend Scheide / Steht ein Herz voll stolzer Träume»; «Seine Neigungen, verkümmert, / Seine Hoffnungen, begraben») - перетворюеться під пером Дросте на скорботну жіночу постать. Але авторка, як щира християнка, висловлюе віру, християнську покору і сподівання на Божу ласку в майбутньому, які допоможуть їй творити, а також розвивати та оберігати чиюсь молодість («nur in der feuchten Scholle / Kann der frische Keim sich hüten»). Філософрiя цього циклу проста на перший погляд: немолода жінка розуміе неможливість щасливого кохання 3 молодим чоловіком. Але у своєму поєднанні вірші цього циклу відкривають глибинні почуття поетеси: не суспільний аспект таких стосунків, а внутрішні конфлікти спричиняють найбільший біль і, водночас, дають найбільшу втіху. Важке рішення дати волю почуттям, непорозуміння і образи, боротьба за володіння серцем і думками коханого, численні поступки, - усе це варте щастя від близькості духовної спорідненої істоти, яке врешті решт примирюе і з майбутньою розлукою, і з наближенням старості. Це щастя єднання нехай короткотривалого, з власною половинкою породжує вдячність за теперішне, смиренність у майбутньому і віру у власну необхідність для молодого коханого, хай навіть у якості його друга, опори і захисника.

Ключові слова: поезія, цикл, стилістика, автор, проблематика, почуття.

Tntroduction. Annette von Droste Hulshoff's 1 poetry concept (Annette von Droste Hulshoff, 1797-1848) in modern philology is deprived of finality of scientific conclusions and designated by problematical character therefore demands a detailed research.

Attention is drawn to the fact that the poetic legacy of an outstanding German poetess is little-known not only to a wide range of readers, but even to philologists. Her lyrics were translated a little, the collection of selected works, especially the collection of works, was not published.
Relevance. The research is very significant since studying the poetry of a given author we study literary heritage of the whole country(in that case Germany) and learn about customs and traditions that reigned in Germany at the beginning of $19^{\text {th }}$ century.

The subject of the study is the poetry of German author Annette von Droste Hulshoff.

The object of the study is the literary heritage of the beginning of 19th century.

The aim of the study is to study works of Annette von Droste Hulshoff, whose writings unjustly 
were disregarded. To find out the main problematic of her poetry and to compare a number of her writing.

Analysis of research and publications. Foreigners (R. Ibel, K. Gezelgauss, G. Guerds, D. Bormeyer, X. Voltaire) and some Soviet literary scholars (M. Rudnitsky, O. Guginin, O. Dmitriev) devoted their work to analyzing the work of "the prominent German lyrical poetess, full of masculine, cardinal strength, marked by the seal of the people of Westphalia, imbued with the impression of a gloomy native landscape, feudal-Catholic world perception and deep religiousness" ("bedeutendste deutsche Lyrikerin von männlicher, kraftvoller Herzheit; geprägt vom westfällischen Volksstamm, Erlebnis der schwermütigsten Heimatlandschaft, feudalkatholischen Weltanschauung und einer tiefen Religiosität”) [4, p. 161].

Basic material. For the analysis of the cycle, the following verses are chosen: "Brennende Liebe", "Die Bank", "An Levin Schücking", "An denselben [Levin Schücking]", "An Levin Schücking [II]", "Abschied von der Jugend" [4, p. 13]. All these works in different degree reproduce love feelings: some are direct addresses, others transmit deep experiences of the lyrical heroine through the descriptive nature of the work.

All of the presented poetry is combined with the perceived awareness of the author of the irresistible difference in the age with his beloved, an understanding of all the obstacles and troubles that bring the love of an old woman to a young man.

Thus, three epistles devoted to L. Shyuking expressly depict the complicated relationships of the lyrical heroine with his beloved: the difference in age leads not only to psychological conflicts but also to the outright misunderstanding of lovers, since the older woman has a greater life experience, she is deprived of selfishness and self-adulation of her youth, she can afford honesty in words and actions in spite of social norms.

The difficult situation of the personal relations which - and Droste understands it - becomes a reason for gossips and jokes ("Worüber alle Lippen freundlich scherzen, // Wir fühlen heil'ger es im eignen Herzen"), is described in the presented cycle, which was originally prepared for publication, with the subtle aesthetics, volume of images and maximalistic categorical judgments peculiar to the poetess: with philosophic calm, the lyrical heroine Droste separates the individual from the public, without hiding from the social conventions, presents to the general public her appeal to her beloved and her perception of the reality of approaching old age.

The poem of Levin Schücking tells story about compliance of such woman before darling whom she really considers the second "I" ("mein Dioskur"): is plot-intonationally based on the idea of paying attention to a sensitive flash - from an emotional manifestation of indignation to a wise understanding and reasoned explanation for the spiritual twin of the importance of a deep feeling, through which one can return relationships: "So reiche mir die Hand, mein Dioskur! / Und mag erneuern sich die holde Mythe, / Wo überm Helm die Zwillingsflamme glühte" [5, p. 30].

The poem "An denselben [Levin Schücking]" is compositionally similar to the previous, not without reason it begins with the lines about the second disorder between the lovers through the word of the lyrical heroine: "Zum zweiten Male will ein Wort / Sich zwischen unsre Herzen drängen" [4, p. 20].

This poetry is the appeal to beloved with a request to take the heroine, despite the flaws, words or actions inherent in her character, for which she justifies, because love makes her better. Despite her inner self-righteousness, the heroine calls for reconciliation ("Sieh her, nicht eine Hand dir nur, / Ich reiche beide dir entgegen"), but as a real woman, she requires understanding and respect for her feelings: "Zum Liebespenden und zum Segen, / Nur ehre ihn, der angefacht / Das Lebenslicht an meiner Wiege" [4, p. 20].

In the poem "An Levin Schücking of [II]" lyrical heroine tired of fight for the relations, for the youth, for possession of heart and thoughts of her beloved. She is helpless before aging and time, her young beloved, except impossibility of the happy union, against will reminds the heroine also of everything that she did not reach, for what she will lack forces: "Und meiner Liebessonne dämmernd Scheinen, / Was noch entschwinden wird und was entschwand, / Das muß ich Alles dann in dir beweinen" [5, p. 40].

The heroine realizes that she is unfortunate in love, she feels that her difference with her beloved will only increase with time, and she will not be able to do anything.

The poem "Brennende Liebe" is a confession to the reader about history of origin of love, about development of the love relations and formation of feelings of the woman through the features and actions of her beloved: "Auch weiß ich eine Gestalt, / So leicht und kräftig zugleich, / Die schreitet vor mir im Wald, / Und gleitet über den Teich" [5, p. 45].

All of his features are considered lyrical heroine especially romantic and displayed in an exaggeratedly attractive form. It is the thin features, movements, words that are formed in the soul of the heroine in the image of an ideal man, and it is this image she is trying hard to save due to a souvenir of love: "Ein Tuch mit Blute genetzt, / Das legte ich heimlich hinein. / Er ritzte sich nur an der Schneide, / Als Beeren vom Strauch er mir hieb" [5, p. 50].

To him the heroine returns again and again, although in the poem there is also no hint of reciprocity of the feelings of the lyrical heroine.

In the poem "Die Bank" we see the course of author's thoughts, which vary depending on the perspective and people in front of her eyes ("Dies ist der Fleck, wo man den Weg / Nach allen Seiten kann bestreichen", "Was mich erfreut, bekümmert, nur / Von drüben kam es hergezogen") [4, p. 34].

Unlike the three epistles, this is a calm, weighed story, and the heroine is a patient martyr of loyalty a woman ready to sit on the bench for hours, only to dip into memories of her beloved again ("Der werten Freunde heitren Bund / Von drüben muß ich ihn erwarten"). It is the conduct of these hours, when the heroine is considered "beloved phantom", is depicted as a usual ritual ("So sitz' ich Stunden wie gebannt, / Im Gestern halb und halb im Heute") [4, p. 48], but the locality and people around - like familiar strangers who have already become an integral part of the symbolic landscape for the heroine.

"Abschied von der Jugend" - is a lyrical and philosophical poetry about parting with youth, in which the lyrical heroine expresses her thoughts about the human age and its inevitable extinction with great expressiveness. A man whose old age 
inexorably approaches is compared with an exile standing on the border of his native land; with the gravedigger that grieves for the dead like a lyrical heroine with her longing for lost opportunities.

The image of a gloomy traveler, in whose heart all expectations and all sorrow are concentrated ("So an seiner Jugend Scheide / Steht ein Herz voll stolzer Träume", "Seine Neigungen, verkümmert, / Seine Hoffnungen, begraben") [5, p. 38] - is transformed under the pen of Droste on the sorrowful female figure. But the author, as a true Christian, expresses faith, Christian humility and hope for God's mercy in the future, which will help her create, as well as develop and preserve someone's youth ("nur in der feuchten Scholle / Kann der frische Keim sich hüten") [4, p. 45].

The philosophy of this cycle is simple at first glance: an elderly woman understands the impossibility of happy love with a young man. But in the combination of verses in this cycle, the deepening feelings of the poetess reveal: not the social aspect of such relationships, and internal conflicts cause the greatest pain and, at the same time, give the greatest satisfaction.

The difficult decision to unleash feelings, misunderstandings and resentment, the struggle for the possession of the heart and thoughts of the beloved, numerous concessions - all this costs happiness from the proximity of a spiritual kindred being, which eventually reconciles with future separation and with the approach of old age.
This happiness of the unity, let it be short-lived, with her own half, gives rise to gratitude for the present, humility in the future, and faith in one's own need for the young lover, even if in the quality of his friend, support and protector.

The language of the cycle is extremely saturated with epithets ("brennende Lieb", "karge Streifen", "geliebte Lüge", "Mein zweites zarteres Gewissen", "voll stolzer Träume") and metaphors ("meiner Seele Brand", "Gletscher ernster Treue", "mir im Herzen springt der Bronnen").

Since a large number of works are poems-appeals, they have a significant number of rhetorical questions ("Wie sollte mir das Herz nicht pochen?", "Ist nicht mein Zürnen selber deinem gleich?", "Du zweifelst an der Sympathie / Zu einem Wesen dir zu eigen?"), exclamatory sentences with interjections ("Wer könnte, ach, wie ich es wissen"; "O, sorglos floß mein Wort und bunt"; "Das Leben ist so kurz, das Glück so selten, / So großes Kleinod, einmal sein statt gelten!"; "So reiche mir die Hand, mein Dioskur!") and repetitions ("Alle stehn am Horizonte, .... Alle kleinen Liebesschätze, ... Alle ihn wie Sünden brennen"), bringing the speaker to life.

Results. Although A. von Froste-Hulshoff is not well-known author her works are worth reading. In her works she doesn't just show love feelings she shows a range of emotions and different kinds of love. But what is important, that in the centre of any plot is the woman, whose life is not easy and who has to make a difficult decision.

\section{References:}

1. Aktualni problemy literaturoznavstva (2000). [Actual problems of literary studies]. Dnipropetrovs'k : SMN. (in Ukrainian)

2. Tihonova O.V. (2008). Istoriya zapadnoevropejskoj literatury XIX veka (romantizm i realizm) : uchebnoe posobie dlya vuzov [The history of West European literature of the XIX century (romanticism and realism)]. Voronezh : Izd-Poligraf. (in Russian)

3. Heselhaus C.A. von Droste-Hülshoff. Werk und Leben (1971). Düsseldorf : DNU.

4. Woesler Fr. Modellfall der Rezeptionsforschung: Droste-Rezeption im 19. Jahrhunder (2006). Bern : Optima.

5. Kemminghausen K.S. Von Droste-Hülshoff (1981). Berlin : Aufl. 